\title{
Faktor Determinan yang Mempengaruhi Kejadian Post Partum Blues pada Ibu Nifas di
} Wilayah Kerja Puskesmas Ibuh Kota Payakumbuh

\section{Debby Yolanda \\ STIKES Yarsi Sumatera Barat}

Korespondensi: debbydiko@gmail.com

DOI: https://doi.org/10.33859/dksm.v10i2.521

\begin{abstract}
Abstrak
Latar Belakang: Post partum dikategorikan sebagai sindroma gangguan mental yang ringan yang terjadi pada masa nifas. Namun sering tidak diperdulikan sehingga tidak terdiagnosis dan tidak ditindak lanjuti sebagaimana seharusnya. Padahal keadaan ini bisa menjadi serius dan bisa bertahan dua minggu sampai satu tahun serta akan berlanjut menjadi depresi dan psikosis post partum. Prevalensi kejadian post partum blues di Indonesia cukup tinggi dengan prevalensi $50-70 \%$. Banyak faktor yang mempengaruhi kejadian post partum blues diantaranya usia, paritas, pekerjaan, pendidikan, pendapatan, dukungan suami dan keluarga dan status kehamilan.

Tujuan: Tujuan penelitian ini adalah untuk mengetahui faktor determinan yang mempengaruhi kejadian post partum blues pada ibu nifas di wilayah kerja Puskesmas Ibuh Kota Payakumbuh tahun 2019. Jenis penelitian ini adalah deskriptif korelatif. Penelitian ini dilakukan di wilayah kerja Puskesmas Ibuh pada bulan Mei-Juli 2019. Populasi dari penelitian ini adalah ibu nifas hari ke 2-7.

Metode: Teknik pengambilan sampel dengan cara consecutive sampling. Instrumen penelitian yang digunakan berupa kuesioner EPDS (Edinburgh Postnatal Depressions Scale) untuk mengukur kejadian post partum blues pada ibu nifas. Teknik analisis data yang digunakan adalah chi square dan regresi logistic berganda.

Hasil: Hasil analisis bivariat didapatkan tiga variabel independen yang berhubungan dengan variable dependen yaitu usia, pekerjaan dan status kehamilan. Hasil analisis multivariat didapatkan bahwa faktor determinan yang mempengaruhi kejadian post partum blues adalah status kehamilan dengan nilai OR 20,598.

Simpulan: Upaya yang bisa dilakukan untuk mencegah kejadian post partum blues dengan pemberian pendidikan kesehatan mengenai perubahan psikologis dan persiapan menghadapi persalinan yang diberikan petugas kesehatan kepada ibu hamil.
\end{abstract}

Kata Kunci: ibu nifas, Post partum blues 
Dinamika Kesehatan Jurnal Kebidanan dan Keperawatan Vol 10 No.2 Desember 2019 ( ISSN: 2086-3454 EISSN: 2549-4058)

url: http://ojs.dinamikakesehatan.unism.ac.id DOI: https://doi.org/10.33859/dksm.v10i2

Faktor Determinan yang Mempengaruhi Kejadian Post Partum Blues pada Ibu Nifas di Wilayah Kerja Puskesmas Ibuh Kota Payakumbuh

\title{
Determinant Factors Affecting Post Partum Blues Occurrence in Postpartum Mothers in the Work Area of Ibuh Public Health Center, Payakumbuh
}

\begin{abstract}
Background: Post partum is categorized as a mild mental disorder syndrome that occurs during the puerperium. However, it is often ignored so it is not diagnosed and not followed up as it should. Though this situation can be serious and can last two weeks to one year and will continue to be depression and post partum psychosis. The prevalence of post partum blues in Indonesia is quite high with a prevalence of 50-70\%. Many factors affect the incidence of post partum blues including age, parity, work, education, income, husband and family support and pregnancy status.

Objective: The purpose of this study was to determine the determinant factors that influence the incidence of post partum blues in postpartum mothers in the working area of Ibuh Payakumbuh City Health Center in 2019. This type of research is descriptive correlative. This research was conducted in the working area of Ibuh Public Health Center in May-July 2019. The population of this study was post-partum mothers day 2-7. The sampling technique is by consecutive sampling.

Method: The research instrument used was a questionnaire EPDS (Edinburgh Postnatal Depressions Scale) to measure the incidence of post partum blues in postpartum mothers. Data analysis techniques used are chi square and multiple logistic regression.

Results: The results of the bivariate analysis found three independent variables related to the dependent variable, namely age, occupation and pregnancy status. The results of multivariate analysis found that the determinant factor that influenced the incidence of post partum blues was pregnancy status with an OR value of 20.598.

Conclusion: Efforts can be made to prevent the post partum blues incident by providing health education regarding psychological changes and preparation for childbirth provided by health workers to pregnant mothers.
\end{abstract}

Keywords: Post partum blues, postpartum mothers

\section{Pendahuluan}

Masa sesudah persalinan akan

membawa perubahan yang sangat besar bagi

seorang ibu, di samping perubahan fisik juga

terjadi perubahan pada kondisi psikologis

(Kurniasari, 2015). Sebagian calon ibu

menganggap bahwa kehamilan dan persalinan

hal yang menegangkan, apabila ibu merasa

tidak nyaman dengan kondisi ini akan mengakibatkan stress pada diri ibu tersebut (Ningrum,2018).

Pada umumnya ibu post partum hanya

mendapat pemenuhan kebutuhan

fisiologisnya saja sementara kebutuhan

psikologisnya tidak terpenuhi. Hal ini sangat

berpengaruh terhadap penurunan kondisi

psikologis ibu post partum disebut dengan

istilah post partum blues. Post partum blues 
Dinamika Kesehatan Jurnal Kebidanan dan Keperawatan Vol 10 No.2 Desember 2019 ( ISSN: 2086-3454 EISSN: 2549-4058)

url: http://ojs.dinamikakesehatan.unism.ac.id DOI: https://doi.org/10.33859/dksm.v10i2

Faktor Determinan yang Mempengaruhi Kejadian Post Partum Blues pada Ibu Nifas di Wilayah Kerja Puskesmas Ibuh Kota Payakumbuh

merupakan kesedihan atau kemurungan

setelah melahirkan, biasanya hanya muncul

sementara waktu, yakni sekitar dua hari hingga dua minggu sejak kelahiran bayi

(Machmudah,2015). Namun sering

dipedulikan, tidak terdiagnosa dan akhirnya tidak ditangani. Yang memiliki dampak buruk terhadap kesehatan ibu dan perkembangan anak (Masruroh, 2013).

Pada penelitian Stone dan Menken (2013) prevalensi post partum blues yang paling tinggi di dunia terdapat di Tanzania yakni sebesar 80\% .Di Asia, prevalensi terjadinya post partum blues yang tertinggi terdapat di negara Pakistan yakni sebesar $75 \%$ (Kurniasari, 2015). Di Indonesia kejadian post partum blues dengan prevalensi 50\%-70\% (Susanti,2016)

Post partum blues disebabkan oleh beberapa faktor yaitu faktor biologis dan faktor psikososial. Faktor biologis meliputi faktor hormonal, faktor kelelahan fisik, dan faktor kesehatan ibu nifas. Faktor psikososial meliputi usia ibu, status paritas, pendidikan ibu nifas, pekerjaan, pendapatan, dukungan suami dan keluarga dan status kehamilan

(Restyana,2014).

Menurut penelitian Rahmawati (2016) post partum blues lebih banyak dialami oleh kurang dari 20 tahu, karena masih rawan untuk merawat anak sehingga mengalami kesulitan sendir dalam beradaptasi.

Pada penelitian lain yang dilakukan oleh Susanti (2016) didapatkan hasil 58,82\% ibu mengalami post partum blues disebabkan oleh status kehamilannya yang tidak diinginkan. Hal ini disebabkan karena akan menimbulkan perasaan penolakan terhadap peran baru sebagai seorang ibu. Pada faktor dukungan suami dan keluarga didapatkan hasil 64,67\%. Dukungan suami dan keluarga merupakan strategi coping yang penting dalam pencegahan stress pada ibu nifas. Karena membangun suasana positif yang memberikan kekuatan sendiri kepada ibu dalam menghadapi peran barunya

Dinas Kesehatan Kota Payakumbuh memiliki 8 Puskesmas dan terdapat 2 puskesmas PONED serta rawat inap. Jumlah semua ibu bersalin di wilayah kerja Puskesmas Ibuh 
Dinamika Kesehatan Jurnal Kebidanan dan Keperawatan Vol 10 No.2 Desember 2019 ( ISSN: 2086-3454 EISSN: 2549-4058)

url: http://ojs.dinamikakesehatan.unism.ac.id DOI: https://doi.org/10.33859/dksm.v10i2

Faktor Determinan yang Mempengaruhi Kejadian Post Partum Blues pada Ibu Nifas di Wilayah Kerja Puskesmas Ibuh Kota Payakumbuh

Kota Payakumbuh pada Tahun 2018 adalah

1016 orang dan tercatat ada 232 orang ibu nifas yang mengalami Post Partum Blues (Profil dinas kesehatan, 2018).

Berdasarkan uraian latar belakang di atas semakin memperkuat peneliti untuk melakukan penelitian dimana terdapat hasil penelitan yang berbeda antara peneliti satu dan lainnya.

\section{Metode}

Jenis penelitian ini adalah bersifat deskriptif korelatif dengan pendekatan Cross sectional. Penelitian ini dilakukan di wilayah kerja Puskesmas Ibuh Kota Payakumbuh tahun 2019. Populasi dalam penelitian ini adalah semua ibu yang melahirkan hari kedua sampai hari ketujuh. Teknik pengambilan sampel pada penelitian ini adalah dengan teknik concecutive sampling dengan jumlah 35 sampel. Instrumen yang digunakan dalam penelitian ini adalah kuesioner yang ditujukan kepada ibu nifas di wilayah kerja Puskesmas Ibuh Kota Payakumbuh berupa kuesioner

\section{EPDS (Edinburgh Postnatal Depression}

Scale) (Machmudah,2015).

\section{Hasil}

Tabel 1. Hubungan antara faktor psikososial terhadap post partum blues pada ibu nifas.

\begin{tabular}{llc}
\hline No & Variabel Independen & P Value \\
& & \\
\hline 1 & Usia & 0,023 \\
2 & Paritas & 0,129 \\
3 & Pendidikan & 0,126 \\
4 & Pekerjaan & 0,026 \\
5 & Pendapatan & 0,129 \\
6 & Dukungan suami dan keluarga & 0,057 \\
7 & Status Kehamilan & 0,026 \\
\hline
\end{tabular}

Berdasarkan analisa bivariat dari 7 faktor yang mempengaruhi kejadian post partum blues pada ibu nifas, terdapat 3 faktor yang signifikan mempengaruhi kejadian post partum blues yaitu usia, pekerjaan dan status kehamilan. 4 faktor lain yang tidak memiliki hubungan adalah paritas, pendidikan, pendapatan serta dukungan suami dan keluarga.

Tabel 2. Faktor determinan yang mempengaruhi kejadian Post Partum Blue pada Ibu Nifas.

\begin{tabular}{|c|c|c|c|c|c|c|c|c|}
\hline \multirow{2}{*}{$\begin{array}{l}\text { Variabe } \\
1 \\
\text { Indepen } \\
\text { den }\end{array}$} & \multirow{2}{*}{ B } & \multirow{2}{*}{ S.E } & \multirow{2}{*}{$\begin{array}{l}\text { Wa } \\
\text { ld }\end{array}$} & \multirow{2}{*}{$\begin{array}{l}\mathrm{d} \\
\mathrm{F}\end{array}$} & \multirow{2}{*}{$\begin{array}{c}P \\
\text { Value( } \\
\text { sig) }\end{array}$} & \multirow{2}{*}{$\begin{array}{c}\text { OR } \\
(\mathrm{Ex} \\
\mathrm{p} \\
(\mathrm{B})\end{array}$} & \multicolumn{2}{|c|}{$95 \%$ CI } \\
\hline & & & & & & & $\begin{array}{l}\text { Lo } \\
\text { wer }\end{array}$ & $\begin{array}{c}\text { Uppe } \\
\mathrm{r}\end{array}$ \\
\hline Usia & $\begin{array}{c}- \\
1,6 \\
57\end{array}$ & $\begin{array}{l}1,0 \\
01\end{array}$ & $\begin{array}{l}2,7 \\
38\end{array}$ & 1 & 0,098 & $\begin{array}{c}0,19 \\
1\end{array}$ & $\begin{array}{c}0,02 \\
7\end{array}$ & $\begin{array}{c}1,35 \\
7\end{array}$ \\
\hline $\begin{array}{c}\text { Pekerja } \\
\text { an }\end{array}$ & $\begin{array}{l}2,5 \\
16\end{array}$ & $\begin{array}{l}1,0 \\
23\end{array}$ & $\begin{array}{c}6,0 \\
48\end{array}$ & 1 & 0,014 & $\begin{array}{c}12,3 \\
76\end{array}$ & $\begin{array}{c}1,66 \\
7\end{array}$ & $\begin{array}{c}91,8 \\
94\end{array}$ \\
\hline $\begin{array}{l}\text { Status } \\
\text { hamil }\end{array}$ & $\begin{array}{l}3,0 \\
43\end{array}$ & $\begin{array}{l}1,3 \\
70\end{array}$ & $\begin{array}{c}4,9 \\
30\end{array}$ & 1 & 0,026 & $\begin{array}{c}20,9 \\
58\end{array}$ & $\begin{array}{c}1,42 \\
9\end{array}$ & $\begin{array}{l}307 \\
420\end{array}$ \\
\hline
\end{tabular}

Berdasarkan analisa multivariat menunjukkan bahwa variabel independen yang dapat dimasukkan kedalam uji 
Dinamika Kesehatan Jurnal Kebidanan dan Keperawatan Vol 10 No.2 Desember 2019 ( ISSN: 2086-3454 EISSN: 2549-4058)

url: http://ojs.dinamikakesehatan.unism.ac.id DOI: https://doi.org/10.33859/dksm.v10i2

Faktor Determinan yang Mempengaruhi Kejadian Post Partum Blues pada Ibu Nifas di Wilayah Kerja Puskesmas Ibuh Kota Payakumbuh

multivariat yang memiliki nilai $\mathrm{p}$ yang signifikan yaitu usia, pekerjaan dan status kehamilan. Faktor determinan yang mempengaruhi kejadian post partum blues pada ibu nifas adalah status kehamilan dengan nilai $\mathrm{OR}=20,958$ kali.

\section{Pembahasan}

\section{Analisa Bivariat}

1. Hubungan usia dengan kejadian post partum blues

Berdasarkan hasil penelitian terhadap 35 orang ibu nifas di wilayah kerja Puskesmas Ibuh Tahun 2019, bahwa dari 14 orang yang memiliki usia beresiko terdapat lebih dari sebagian besar $(78,6 \%)$ mengalami kejadian post partum blues yaitu sebanyak 11 orang. Hasil analisis statistik dengan chi-square diperoleh nilai $\mathrm{p}$ sebesar 0,023 , artinya ada hubungan yang signifikan antara usia dengan kejadian post partum blues pada ibu nifas di wilayah kerja Puskesmas Ibuh tahun 2019.

Hasil penelitian ini sesuai dengan penelitian yang dilakukan oleh (Kurniasari, 2015) menyatakan bahwa kejadian post partum blues lebih banyak dialami oleh wanita umur beresiko. Dengan hasil penelitian didapatkan angka signifikasi 0,040 dengan nilai OR 2,700 berarti umur beresiko memiliki peluang 2,700 kali lebih besar untuk mengalami post partum blues.

Menurut Slone dan Benedict dalam Machmudah (2015) usia yang dianggap optimal untuk kehamilan dan persalinan adalah antara 20-30 tahun dan hal ini mendukung periode yang optimal bagi ibu untuk merawat bayinya. Usia dibawah 20 tahun memiliki pengetahuan yang terbatas tentang kehamilan dan belum cukup untuk mencapai kematangan fisik, mental, peran dan aktivitas baru sebagai ibu dalam merawat bayinya.

Berdasarkan hasil penelitian yang dilakukan, peneliti mengambil kesimpulan bahwa ibu nifas yang memiliki usia yang beresiko lebih cenderung mengalami kejadian post partum blues daripada ibu nifas yang memiliki usia yang tidak beresiko. Hal ini disebabkan karena pada usia kurang dari 20 tahun seorang wanita masih sangat rawan 
Dinamika Kesehatan Jurnal Kebidanan dan Keperawatan Vol 10 No.2 Desember 2019 ( ISSN: 2086-3454 EISSN: 2549-4058)

url: http://ojs.dinamikakesehatan.unism.ac.id DOI: https://doi.org/10.33859/dksm.v10i2

Faktor Determinan yang Mempengaruhi Kejadian Post Partum Blues pada Ibu Nifas di Wilayah Kerja Puskesmas Ibuh Kota Payakumbuh

untuk merawat bayi sehingga mengalami

kesulitan untuk beradaptasi dalam masa nifas.

Sedangkan wanita yang usia tua cenderung mengalami lebih banyak beban psikologis seperti kesehatan fisik yang menurun dan memiliki tingkat kecemasan yang lebih tinggi.

2. Hubungan pekerjaan dengan kejadian post

\section{partum blues}

Berdasarkan hasil penelitian terhadap 35 orang ibu nifas di wilayah kerja Puskesmas Ibuh Tahun 2019 bahwa dari 16 orang ibu nifas yang tidak bekerja terdapat sebagian besar $(75 \%)$ mengalami kejadian post partum blues yaitu sebanyak 12 orang. Hasil analisis statistik dengan chi-square diperoleh nilai $\mathrm{p}$ sebesar 0,026 dengan demikian Ho ditolak dan Ha diterima yang berarti bahwa ada hubungan yang signifikan antara pekerjaan dengan kejadian post partum blues pada ibu nifas di wilayah kerja Puskesmas Ibuh tahun 2019.

Hasil penelitian ini sesuai dengan penelitian yang dilakukan oleh Anoraga (2008) dalam Fatmawati mengemukakan bahwa wanita pekerja lebih banyak akan kembali pada rutinitas bekerja setelah melahirkan dan cendrung memiliki peran ganda yang menimbulkan gangguan emosional.

Hal ini sesuai dengan Fatmawati (2015) yang menyatakan bahwa ibu yang tidak bekerja lebih cenderung mudah mengalami kejadian post partum blues karena wanita yang tidak bekerja kurangnya informasi yang didapat dari lingkungan sekitar dan lingkungan pergaulannya. Atau bisa juga dengan peningkatan kecemasan yang tinggi karena mempunyai cukup informasi sehingga membuat takut akan akibat yang dapat ditimbukan dari informasi itu.

3. Hubungan status kehamilan dengan kejadian post partum blues

Berdasarkan hasil penelitian terhadap 35 orang ibu nifas di wilayah kerja Puskesmas Ibuh Tahun 2019 bahwa dari 9 orang ibu nifas yang tidak menginginkan kehamilannya, terdapat lebih dari sebagian besar $(88,9 \%)$ mengalami kejadian post partum blues yaitu sebanyak 8 orang. Hasil analisis statistik 
Dinamika Kesehatan Jurnal Kebidanan dan Keperawatan Vol 10 No.2 Desember 2019 ( ISSN: 2086-3454 EISSN: 2549-4058)

url: http://ojs.dinamikakesehatan.unism.ac.id DOI: https://doi.org/10.33859/dksm.v10i2

Faktor Determinan yang Mempengaruhi Kejadian Post Partum Blues pada Ibu Nifas di Wilayah Kerja Puskesmas Ibuh Kota Payakumbuh

dengan chi-square diperoleh nilai $\mathrm{p}$ sebesar 0,026 dengan demikian Ho ditolak dan $\mathrm{Ha}$ diterima yang berarti bahwa ada hubungan yang signifikan antara status kehamilan dengan kejadian post partum blues pada ibu nifas di wilayah kerja Puskesmas Ibuh tahun 2019.

Penelitian ini sesuai dengan penelitian yang dilakukan oleh Susanti (2016) menyatakan bahwa kehamilan yang tidak diinginkan beresiko terhadap kejadian postpartum blues, karena ibu mempunyai perasaan tidak ingin merawat bayinya karena merasa tidak menginginkan kehamilan tersebut.

Sesuai dengan teori yang disampaikan oleh Bobak (2014) bahwa dengan kehamilan yang diharapkan maka seorang ibu akan semakin siap untuk persalinan dan menjadi ibu. Persiapan untuk persalinan dan menjadi ibu akan sangat menentukan apakan seseorang mengalami post partum blues atau tidak. Adanya persiapan yang baik membuat ibu post partum akan mampu menghadapi masa pasca persalinannya dengan baik.

\section{Analisa Multivariat}

Berdasarkan uji regresi linier berganda dengan metode enter didapatkan faktor determinan yang mempengaruhi kejadian post partum blues pada ibu nifas di wilayah kerja Puskesmas Ibuh Tahun 2019 adalah status kehamilan dengan nilai signifikansi 0,026 dengan nilai $\mathrm{OR}=20,958$ kali. Hal ini berarti bahwa status kehamilan mempengaruhi kejadian post partum blues pada ibu nifas sebanyak 20,958 kali.

Seorang ibu yang kehamilannya sangat diharapkan maka seorang ibu akan semakin siap untuk persalinan dan siap menjadi ibu. Persiapan untuk persalinan dan menjadi ibu akan sangat menentukan apakan seseorang mengalami post partum blues atau tidak. Adanya persiapan yang baik membuat ibu post partum akan mampu menghadapi masa pasca persalinannya dengan baik (Bobak, 2014).

Ada beberapa kejadian yang biasanya mendahului unwanted pregnancy, meskipun kehamilan didapatkan dalam pernikahan. Antara lain jumlah anak sudah cukup banyak, 
Dinamika Kesehatan Jurnal Kebidanan dan Keperawatan Vol 10 No.2 Desember 2019 ( ISSN: 2086-3454 EISSN: 2549-4058)

url: http://ojs.dinamikakesehatan.unism.ac.id DOI: https://doi.org/10.33859/dksm.v10i2

Faktor Determinan yang Mempengaruhi Kejadian Post Partum Blues pada Ibu Nifas di Wilayah Kerja Puskesmas Ibuh Kota Payakumbuh

merasa umur terlalu tua untuk hamil, riwayat kehamilan atau persalinan sebelumnya yang penuh penyulit dan komplikasi, alasan ekonomi, merasa terlanjur mengonsumsi obat atau menderita kelainan yang dikhawatirkan membuat cacat pada anak, riwayat melahirkan anak cacat (mungkin lebih dari satu kali), pasangan suami istri di ambang perpecahan, dan kegagalan penggunaan alat $\mathrm{KB}$ atau kontrasepsi.

Ibu nifas yang kehamilannya tidak diinginkan akan lebih mudah untuk mengalami kejadian post partum blues dibandingkan ibu nifas yang kehamilannya diinginkan, karena kehamilan yang tidak diinginkan akan menimbulkan perasaan penolakan terhadap peran baru sebagai seorang ibu. Ibu dengan status kehamilan yang tidak diinginkan akan memiliki perlakukan yang berbeda pada bayinya dibandingkan dengan ibu nifas yang memiliki status kehamilan yang diinginkan. Karena status kehamilan memiliki pengaruh kuat terhadap kondisi psikologis ibu nifas dalam menghadapi masa kehamilan dan masa kelahiran bayinya.

\section{Simpulan}

Berdasarkan hasil penelitian yang dilakukan, peneliti mengambil kesimpulan bahwa ibu nifas yang kehamilannya tidak diinginkan akan lebih mudah untuk mengalami kejadian post partum blues dibandingkan ibu nifas yang kehamilannya diinginkan, karena kehamilan yang tidak diinginkan akan menimbulkan perasaan penolakan terhadap peran baru sebagai seorang ibu.

\section{Ucapan terima Kasih}

Dengan selesainya penelitian ini kami mengucapkan terima kasih kepada kepala Puskesmas Ibuh Kota Payakumbuh dan responden wilayah kerja Puskesmas Ibuh Kota Payakumbuh yang telah memberikan bantuan kerjasama sampai terlaksananya penelitian ini dengan lancar dan baik. 


\section{Daftar Pustaka}

Kurniasari, D., \& Astuti, Y. A. (2015). Hubungan Antara Karakteristik Ibu, Kondisi Bayi dan Dukungan Sosial Suami dengan Postpartum Blues pada Ibu Dengan Persalinan SC di Rumah Sakit Umum Ahmd Yani Metro Tahun 2014. JUrnal Kesehatan Holistik, 9(3), 115-125. Retrieved from http://ejurnalmalahayati.ac.id/index.ph $\mathrm{p} /$ holistik/article/view/215/154

Susanti, L. W. (2016). Faktor Terjadinya Baby Blues Syndrom pada Ibu Nifas di BPM Suhatmi Puji Lestari. Maternity : Jurnal Kebidanan Dan Ilmu Kesehanatan, 3(2).

Bobak, I.M., Lowdermilk, D.L., \& Jensen, M.D. (2014).Buku ajar keperawatan maternitas. (Maria \& Peter, Penerjemah). Edisi 4.Jakarta : EGC.

Ningrum, S. P. (2018). Faktor-Faktor Psikologis yang Mempengaruhi Postpartum Blues. Psympathic: Jurnal Ilmiah Psikologi, 4(2), 205-218. https://doi.org/10.15575/psy.v4i2.1589
Rahmawati, F., \& Sulistyowati. (2016). Gambaran Ibu Postpartum dengan Baby Blues. Jurnal Kesehatan Ibu Dan Anak Akademi Kebidanan An-Nur, 1, 15-20.

Restyana, C. I., Adiesti, F., Politeknik, M., Majapahit, K., \& Politeknik, D. (2014). Kejadian Baby Blues Pada Ibu Primipara Di Rsud Bangil Pasuruan. Hospital Majapahit, 6(2), 29-39.

Masruroh. (2013). Hubungan antara paritas ibu dengan kejadian postpartum blues. Polindes Desa Permisan Kecamatan Jabon Kabupaten Sidoarjo, 3(2).

Machmudah. (2015). Gangguan Psikologis Pada Ibu Postpartum ; 3(2), 118-125.

Fatmawati, D. A. (2015). Faktor resiko yang berpengaruh terhadap kejadian postpartum blues: jurnal edu health, 5(2).

Stone, S. D., Menken, A. E., 2008, Perinatal and Postpartum Mood Disorders : Perspectives and Treatment Guide for the Health Care Practitioner, Springer Publishing Company, NY, 67-70 